\title{
Motivation for assistance activities among hospice, missionary and sport volunteers
}

\begin{abstract}
The aim of the study is to analyze motivation for undertaking activities to help others by people involved in various forms of volunteer work. We analyzed two sources of motivation: moral endo-exocentrism and the value system among three groups: hospice, missionary and sports volunteers. The study involved 173 people between 16 to 77 years of age, 59 giving service in a hospice, 63 in missionary activities and 51 as sports volunteers. We applied the Moral Endo-Exocentrism Questionnaire (MEEQ) by Karyłowski, Górski and Wasiak and the Portraits Questionnaire (PVQ) by Schwartz. The study showed higher levels of exocentric than endocentric motivation among the three groups of volunteers. However, the intergroup value preference comparison revealed 7 values which significantly differentiated hospice, missionary and sports volunteers: Tradition, Hedonism, Success, Power, Self-Directing, Stimulation and Universalism.
\end{abstract}

\section{Keywords}

Endo-exocentrism, values, volunteering, pro-social behavior.

\section{Introduction}

The phenomenon of volunteering is of interest to philosophers, theologians, sociologists, pedagogues and psychologists. In psychology, for a long time, this issue has been understood on the basis of wider pro-social behaviors. Much attention is paid to analyzing the motivation which drives a person to engage 
in activities for other people. ${ }^{1}$ Volunteering in a wide variety of ways is an example of such activity for others. ${ }^{2}$ In the literature, there is a debate about whether people involved in the support services are guided by self-centered, selfish, unworthy of recognition motivations, or altruistic, self-less, admirable motivations. ${ }^{3}$ Extensive and long-term research on volunteering was carried out by the Klon/Jawor Association.

Baczko and Ogrodzka ${ }^{4}$, the authors of the study conducted in 2007 , noted that respondents were asked about the reasons for engaging in prosocial work (e.g. sacrificing their free time, giving their money to charity), and these people claimed that moral, religious or political convictions required them to help others. The second reason for volunteering was counting on reciprocation in the future, and next was helping others for pleasure and the opportunity to be with other people. ${ }^{5}$ Three years later, a similar study was conducted by Przewłocka. ${ }^{6}$ Searching for the motives for doing volunteer work, she got slightly different answers. The respondents felt that working to help other people just makes them happy and they are simply interested in doing so. A less often mentioned

${ }^{1}$ Cf. J. Karyłowski, O dwóch typach altruizmu: Badania nad endo-i egzocentrycznymi źródłami podejmowania bezinteresownych działań na rzecz innych ludzi, Wrocław 1982, Ossolineum; J. Reykowski, Motywacja, postawy prospołeczne a osobowość, Warszawa 1979, Państwowe Wydawnictwo Naukowe; J. Śliwak, Osobowość altruistyczna: Osobowościowe korelaty altruizmu: psychologiczne badania empiryczne, Lublin 2001, Redakcja Wydawnictw Katolickiego Uniwersytetu Lubelskiego; J. Śliwak, Altruizm a preferencja wartosci. Badania empiryczne, „Roczniki Filozoficzne” 4 (1996), pp. 111-146.

${ }^{2}$ Z. Cendrowski, Wolontariusze, Warszawa 1998, Zarząd Główny Szkolnego Związku Sportowego. Agencja „Promo Lider”; L. Pawłowski, M. Lichodziejewska-Niemierko, Wolontariat w opiece paliatywnej i hospicyjnej w Polsce-aspekty prawne, „Medycyna Paliatywna w Praktyce” 3 (2010) 4, pp. 125-132; D. Pietrowski, Wolontariat w Polsce - nowe spojrzenie na prace społeczna, „Roczniki Naukowe Caritas” 5 (2001).

${ }^{3}$ M. Oliwa-Ciesielska, Dobro jednostki versus dobro wspólne - paradoksy przeciwności, in: B. Kromolicka (ed.), Dobro jednostki versus dobro wspólne - paradoksy przeciwności, Akapit, Toruń 2005, pp. 57-63; A. Basińska, M. Nowak, Motywowanie i motywacja do pracy wolontariuszy, Poznań 2010, WOLIMP.

${ }^{4}$ A. Baczko, A. Ogrocka, Wolontariat, filantropia i 1\%: Raport z badań 2007, Warszawa 2008, Stowarzyszenie Klon/Jawor.

5 Cf. A. Basińska, M. Nowak, Motywowanie wolontariuszy, http://www.staff.amu.edu.pl/ $\sim$ wolimp/Do\%20pobrania:/article/100/Basinska_Anita_Nowak_Marek-Motywowanie_ wolontariuszy.pdf (25.03.2015).

${ }^{6}$ J. Przewłocka, Zaangażowanie społeczne Polaków w roku 2010: Wolontariat, filantropia, 1\%: raport z badań, Warszawa 2011, Stowarzyszenie Klon/Jawor. 
motivation was counting on reciprocal help in the future. Values that can be achieved by volunteer work were put in third place.

A study on volunteers working in hospices and palliative care centers was conducted by Antos, Kowalik and Kopański. ${ }^{7}$ The authors conclude that the main motivation that encouraged volunteers to help the sick and suffering was the need to help these people and offer them their free time.

In the context of these studies, it seems reasonable, therefore, to ask about the sources of a volunteer's motivation, that is why be involved in various activities for the benefit of other people? This question is even more interesting since in contemporary reality we can meet with the assertion or even suspicion that volunteering is rarely dictated by inner necessity, a preferred system of values and heartfelt care. Increasingly, all activities are controlled by professional bureaucrats, who prepare propaganda strategies whose aim is to encourage Poles to undertake certain initiatives. The importance of the question concerning motivation is also raised by Basińska and Nowak ${ }^{8}$, who note that gaining knowledge about the motivation to do volunteer work and the search for effective instruments of motivation is very important because of the important role of voluntary activities.

The goal of this study is to analyze the motivation for undertaking activities aimed to help other people by those involved in different forms of volunteering. The heart of the analysis includes two sources of motivation to help: moral endo-exocentrism and the values system. We studied missionary, sports and hospice volunteers. The next part defines the phenomenon of volunteering, where we present the concept of endo- and exocentricity, Schwartz's values model and our research hypotheses.

\section{Volunteering as a Form of Outreach Activities}

According to the Act on public benefit activity and volunteer work of April 24, 2003, a volunteer is a person who voluntarily, and without pay, performs services pursuant to this Act. According to Pietrowski ${ }^{9}$, volunteering is conscious,

${ }^{7}$ E. Antos, K. Kowalik, Z. Kopański, Postrzeganie hospicjum i opieki paliatywnej przez wolontariuszy, „palliative care by charity workers). Journal of Public Health, Nursing and Medical Rescue" (2012) 2, pp. 48-51.

8 A. Basińska, M. Nowak, Motywowanie i motywacja do pracy wolontariuszy.

${ }^{9}$ D. Pietrowski, Wolontariat w Polsce - nowe spojrzenie na prace społeczna. 
free of charge, selfless and voluntary work for the benefit of other people, not including collegial relationships or family members. Also, Pawłowski and Lichodziejewska-Niemirko ${ }^{10}$ emphasize that volunteering is a social phenomenon consisting in voluntary and unpaid volunteers performing services in various organizations entitled to this type of work. ${ }^{11} \mathrm{~A}$ volunteer freely chooses to undertake helpful activities for other people. ${ }^{12} \mathrm{~A}$ voluntary attitude and working free of charge are therefore the basic characteristics of volunteering. A volunteer recognizes the problems others have, their personal capacity to cope with these problems and discovers the need to undertake assistance, performed either as an individual volunteer or in professionally organized groups. ${ }^{13}$

In response to the question "Who can be a volunteer?", there is no clear answer in the literature. While Olubiński ${ }^{14}$ argues that people can help others in each and every aspect of life, Witkowski ${ }^{15}$ stresses the need for professionalism in these activities. He believes that a person not having the appropriate qualifications for prosocial work, in spite of good intentions, may cause harm in their engagements. The lack of appropriate skills, therefore, refutes the myth saying that every person can and should help the needy. Witkowski ${ }^{16}$ strongly emphasizes that the relationship that results from the relief effort needs to be seen as being meaningful. Voluntary activity also assumes a certain continuity and systematic actions for people in need. Volunteering not always concerns activities addressed directly to another person. It may include activities in favor

${ }^{10}$ L. Pawłowski, M. Lichodziejewska-Niemierko, Wolontariat $w$ opiece paliatywnej i hospicyjnej w Polsce-aspekty prawne, pp. 125-132.

${ }^{11}$ Cf. also A. Basińska, M. Nowak, Motywowanie i motywacja do pracy wolontariuszy.

12 Z. Cendrowski, Wolontariusze.

13 T. Kaminski, Praca socjalna i charytatywna, Warszawa 2004, Wydawnictwo Uniwersytetu Kardynała Stefana Wyszynskiego.

${ }^{14}$ A. Olubiński, Humanistyczno-edukacyjne wartości wolontariatu w przygotowaniu do pracy socjalnej, in: B. Kromolicka (ed.), Humanistyczno-edukacyjne wartości wolontariatu w przygotowaniu do pracy socjalnej, Akapit, Toruń 2005, pp. 47-55.

${ }^{15}$ L. Witkowski, Człowiek i profesjonalizm w pracy socjalnej (czyli jak bronić wolontariat przed woluntaryzmem - spojrzenie filozofa), in: B. Kromolicka (ed.), Człowiek i profesjonalizm $w$ pracy socjalnej (czyli jak bronić wolontariat przed woluntaryzmem - spojrzenie filozofa), Akapit, Toruń 2005, pp. 19-45.

${ }^{16}$ L. Witkowski, Człowiek i profesjonalizm w pracy socjalnej (czyli jak bronić wolontariat przed woluntaryzmem - spojrzenie filozofa), pp. 19-45. 
of environmental protection, animal care, or an activity aimed at protecting and multiplying the values and goods that serve mankind. ${ }^{17}$

Forms of volunteer work. Sometimes the concept of volunteering is associated only with the activities of assisting the sick, disabled or children living in orphanages. In fact, it has a much wider scope and covers more diverse aspects of social life, such as e.g. health (hospice volunteers), social assistance (volunteers cooperating in social assistance centers), culture (in cooperation with cultural institutions), the environment (the involvement of volunteers to work in parks or botanical gardens), schools (school volunteer clubs), and sports (the organization of sports events). ${ }^{18}$

The present study includes three types of volunteer work: hospice, missionary and sports. Hospice volunteering means accompanying the sick, helping them through personal care such as washing or dressing, assisting in moving someone, helping to prepare meals, feeding or taking care of small matters. The complex system of attitudes, relationships and bonds emerging between the volunteer and the ward seems to be extremely important. ${ }^{19}$ The range of experiences of a volunteer at a hospice include: being present at a sick person's side, the ability to listen, closeness, the ability to show compassionate love, respecting the patient's individuality and privacy, a humble attitude towards the disease and respect for the suffering. ${ }^{20}$ According to de Walden-Gałuszko ${ }^{21}$, when caring for patients, we should first assess what their needs are in specific areas, because people who are seriously ill (regardless of age, education, social status or the type of work) have specific kinds of needs. De Walden-Gałuszko points to the special role of hospice volunteers when they assist the terminally

17 Z. Cendrowski, Wolontariusze; T. Kamiński, Wolontariat w placówkach pomocy instytucjonalnej, „Roczniki Naukowe Caritas” 5 (2001), pp. 99-109.

${ }_{18}$ M. Ochman, P. Jordan, Jak pracować z wolontariuszami?, Warszawa 2000, Biuro Obsługi Ruchu Inicjatyw Społecznych BORIS; J. Śliwak, M. Zdunek, Wolontariat - bezinteresowna działanie na rzecz potrzebującego, in: J. Śliwak (ed.), Wolontariat - bezinteresowna działanie na rzecz potrzebującego, Norbertinum, Lublin 2007, pp. 103-126.

19 B. Kromolicka, Wolontariusz w służbie człowiekowi umierającemu: Na przykładzie Szczecińskiego Hospicjum Domowego, Szczecin 2000, Pedagogium.

${ }^{20}$ Cf. H. Klimaszewska, Wolontariat $w$ stużbie potrzebującym, in: C. Opalach (ed.), Wolontariat w stużbie potrzebującym, Lubelskie Hospicjum dla Dzieci im. „Małego Księcia”, Lublin 2004, pp. 7-14.

${ }^{21}$ K. de Walden-Gałuszko, Opieka holistyczna, in: P. Krakowiak, J. Binnebesel, K. de Walden-Gałuszko, A. Modlińska (eds.), Opieka holistyczna, „Via Medica”, Gdańsk 2008, pp. 319-320. 
ill in overcoming the unpleasant feeling of loneliness. ${ }^{22}$ This feeling of isolation in harsh conditions usually increases.

Mission volunteer work is basically helping missionaries in mission countries by meeting the needs of worldly neglect in helping the poorest people who have been socially marginalized. A mission volunteer's assignments include: 1. mission animation, among others helping set up displays promoting the missions, competitions on knowledge about the missions, organizing meetings with missionaries, showing movies and presentations on mission topics; 2. material support, for example fundraising, collecting clothes, medicine, school supplies, organizing mission festivals and displays with handmade artistic things and objects brought from the missions; 3 . acquiring experience for missionary work by volunteering in orphanages, social nursing homes, working with the youth, organizing educational, language and integration activities in community centers and oratories; and 4. helping missionaries at the missions in various countries. Missionary volunteer work also develops sensitivity to other people who have a different skin color, refugee status or who come from another country.

Sports volunteers judge competitions, keep records of competitions, help to organize sporting events, for example by preparing sports facilities, securing competition routes, assisting in giving awards. They are responsible for maintenance and office work, supervise the safety of the event, belong to the medical services, the anti-dope commission, and keep statistics and scoreboards. More and more organizations, associations or clubs are looking for people who want to support their work and get involved in their development. The involvement of sports volunteers often guarantees success when organizing a sports event.

The above-mentioned types of volunteer work emphasize different objectives and require different competencies. A hospice volunteer should be sensitive and have a hierarchy of values, allowing him to confront other person's illness, suffering or death. The sensitivity of the missionary volunteer should meet the challenges of poverty and hunger in mission countries and promote openness to socio-cultural diversity. However, the sports volunteer must focus on success, activity, creativity and effectiveness in action. The "demand" for a different type of sensitivity among these different types of volunteer work raises a legitimate question about the differences in the motivation of people engaging in hospice, missionary and sports volunteer activities.

${ }^{22}$ K. de Walden-Gałuszko, Opieka holistyczna, pp. 319-320. 


\section{Motivation for Support Behavior}

Any form of voluntary activity is work done out of one's free-will, aimed at caring for the good of another person and one's environment without expecting financial profit or other material benefits. The motivation accompanying prosocial behavior is complex. However, since there are different motives of social behavior, including prosocial behavior ${ }^{23}$, we can also expect to find various motivations among the people involved in various forms of voluntary work. ${ }^{24}$ Apart from the non-specific sources of motivation (e.g. the need for stimulation) and pseudo-altruistic behavior motivated by the search for external reinforcements, we can point to endo- and exocentric morals and the preferred system of values as two potential sources that activate relief efforts. ${ }^{25}$

Endocentric and exocentric morality. The mechanism of endo- and exocentric morals allows differentiating the stimulus that catalyses service behavior. ${ }^{26}$ The exocentric drive signals such behavior coming from the outside. Such activity is motivated by the desire to produce the desired change (or not causing undesirable changes) in another person's situation. Other person is perceived as an autotelic value, and the subject's attention is focused on the external world,

${ }^{23}$ Cf. J. Karyłowski, Socjalizacyjne determinaty endo- egzocentryzmu moralnego, „Studia Psychologiczne" 2 (1982) 20, pp. 77-88; J. Karylowski, Two types of altruistic behavior, in: J. Grzelak, V. J. Derlega (eds.), Two types of altruistic behavior, Academic Press, New York 1982, pp. 397-413; J. Śliwak, Niepokój a poziom altruizmu, „Przegląd Psychologiczny: organ Polskiego Towarzystwa Psychologicznego" (2002); J. Śliwak, Altruizm endo-i egzocentryczny a poziom niepokoju, „Analecta Cracoviensia” (1996) 28, pp. 143-159.

${ }^{24}$ E. Staub, Positive social behavior and morality: Social and personal influences, New York 1978, Academic Press; J. Reykowski, Motywacja, postawy prospołeczne a osobowość; J. Rushton, The altruistic personality, in: J. Philippe Rushton, R. M. Sorrentino (eds.), The altruistic personality. Social, personality, and developmental perspectives, L. Erlbaum Associates, Hillsdale, NJ 1981, pp. 251-266.

${ }^{25}$ Cf. J. Karyłowski, Focus of attention and altruism: endocentric and exocentric sources of altruistic behavior, in: E. Staub, D. Bar-Tal, J. Karylowski, J. Reykowski (eds.), Focus of attention and altruism: endocentric and exocentric sources of altruistic behavior. International Perspectives on Positive Morality, Springer US, Boston, MA 1984, pp. 139-153.

${ }^{26}$ J. Karyłowski, Explaining altruistic behavior, „Polish Psychological Bulletin” 1 (1977) 8, pp. 27-34; J. Karyłowski, O dwóch typach altruizmu; J. Karyłowski, Koncentracja na sobie i zawartość „ja” idealnego, a bezinteresowne działania na rzecz innych ludzi, „Studia Psychologiczne" 1 (1977) 16, pp. 19-36; G. Kochańska, Regulatory theory of personality and the development of prosocial behaviors, in: E. Staub, D. Bar-Tal, J. Karylowski, J. Reykowski (eds.), Regulatory theory of personality and the development of prosocial behaviors. International Perspectives on Positive Morality, Springer US, Boston, MA 1984, pp. 155-176. 
meaning on the situation, needs and feelings of the person who is in need, and not on his own "I". In the case of endocentrism, the motivation to act and help comes from within the subject. The subject's concentration is focused not so much on the partner but rather on themselves, and more specifically on the moral aspect of the "I", and the activity is motivated by the desire to cause the desired change (or not cause an undesirable change) according the their self-image. ${ }^{27}$ In our present study, we made comparisons between hospice, missionary and sports volunteers regarding the intensity of endo- or exocentric motivation.

The value system. The value system is an important trigger for motivational processes. The present study includes the values model proposed by Shalom H. Schwartz. ${ }^{28}$ This model has drawn the great interest of researchers and has been confirmed in studies conducted in different cultures. ${ }^{29}$ Schwart $z^{30}$ defined it as the cognitive representation of motivation (usually conviction), worthy of being desired, with a goal beyond the actual situation. ${ }^{31}$ Schwartz ${ }^{32}$ identified 10 types of values, each of which is defined by its own target incentive: hedonism, stimulation, self-direction, universalism, benevolence, tradition, conformity, security, power and success. ${ }^{33}$ Table 1 shows each of the 10 types of values, the motivational goal and the sample characteristics used for measuring it.

According to Schwartz ${ }^{34}$, values are arranged in a two-dimensional space in the form of a circle relative to each other in correlation bonds (see. Figure 1). The goal centered values are positively correlated and occupy a contiguous place

${ }^{27}$ Cf. J. Karylowski, Two types of altruistic behavior, pp. 397-413.

${ }^{28}$ S. Schwartz, Are there universal aspects in the structure and contents of human values?, "Journal of social issues" 4 (1994) 50, pp. 19-45; S. Schwartz, Universals in the content and structure of values, „Advances in experimental social psychology” (1992) 25, pp. 1-65.

29 P. Brzozowski, Uniwersalność struktury wartości. Koncepcja Shaloma H. Schwartza, „Roczniki Psychologiczne” 5 (2002), pp. 27-52; S. Schwartz, T. Rubel-Lifschitz, Cross-national variation in the size of sex differences in values, "Journal of personality and social psychology" 1 (2009) 97, pp. 171-185.

${ }^{30}$ S. Schwartz, Are there universal aspects in the structure and contents of human values?, pp. 19-45.

${ }^{31}$ Cf. J. Cieciuch, Kształtowanie sie systemu wartości od dzieciństwa do wczesnej dorosłości, Stare Kościeliska 2013, Wydawnictwo Liberi Libri.

${ }^{32}$ S. Schwartz, Are there universal aspects in the structure and contents of human values?, pp. 19-45.

${ }^{33}$ S. Schwartz, Universals in the content and structure of values, pp. 1-65.

${ }^{34}$ S. Schwartz, Universals in the content and structure of values, pp. 1-65. 
on the two-dimensional space. Values having opposing goals correlate negatively and are located opposite to each other.

Table 1. Types of values in Schwartz's model (1992) (cf.: Schwartz, RubelLifschitz, 2009, p. 172).

\begin{tabular}{|c|c|c|}
\hline Value & Goal of Motivation & Examples of Positions \\
\hline Hedonism & $\begin{array}{l}\text { Pleasure, gratification through sensual } \\
\text { pleasure }\end{array}$ & $\begin{array}{l}\text { Pleasure, reaping the joy of life, fun, indulg- } \\
\text { ing }\end{array}$ \\
\hline Stimulation & Excitement, novelty and life challenges & $\begin{array}{l}\text { Excitement in life, passion for adventure, } \\
\text { risk, courage }\end{array}$ \\
\hline Self-directing & $\begin{array}{l}\text { Independent thinking and action, creativity, } \\
\text { exploration }\end{array}$ & $\begin{array}{l}\text { Creativity, freedom, independence, curios- } \\
\text { ity }\end{array}$ \\
\hline Universalism & $\begin{array}{l}\text { Understanding, respect, tolerance and pro- } \\
\text { tecting other's property and nature }\end{array}$ & $\begin{array}{l}\text { Social justice, equality, wisdom, peace } \\
\text { in the world, environmental protection }\end{array}$ \\
\hline Kindness & $\begin{array}{l}\text { Protecting and improving the welfare } \\
\text { of close people }\end{array}$ & Helpful, caring, loyal, supportive \\
\hline Tradition & $\begin{array}{l}\text { Respect, commitment and acceptance } \\
\text { of traditional and religious customs and } \\
\text { values }\end{array}$ & $\begin{array}{l}\text { Respect for tradition, humility, zeal, mod- } \\
\text { esty }\end{array}$ \\
\hline Conformity & $\begin{array}{l}\text { Abstaining from activities, inclinations and } \\
\text { impulses that may offend or harm others } \\
\text { or violate social norms }\end{array}$ & Following the rules, obedience, respect \\
\hline Safety & $\begin{array}{l}\text { Security, harmony and stability in relation- } \\
\text { ships, social order and stability of the "l" }\end{array}$ & $\begin{array}{l}\text { Family safety, social order, neatness, } \\
\text { avoiding danger }\end{array}$ \\
\hline Power & $\begin{array}{l}\text { Social status, prestige, control or domi- } \\
\text { nance over people and resources }\end{array}$ & $\begin{array}{l}\text { Power, wealth, controlling others, social } \\
\text { impact }\end{array}$ \\
\hline Success & $\begin{array}{l}\text { Achieving personal success by exposing } \\
\text { one's competence in accord with social } \\
\text { standards }\end{array}$ & $\begin{array}{l}\text { Success, ambition and admiration for pos- } \\
\text { sessed abilities }\end{array}$ \\
\hline
\end{tabular}

Schwartz suggested that the relationship between these values is also expressed by two bipolar dimensions ${ }^{35}$ : Openness to change versus Conservatism and Strengthening the "I" versus Overcoming the "I" (cf. Figure 1). The first dimension is opposed to values emphasizing independent thinking and action and

${ }^{35}$ S. Schwartz, Are there universal aspects in the structure and contents of human values?, pp. 19-45. 
prefers changes and new stimulus (Self-direction and Stimulation), emphasizing the values of submitting to the rules, accepting tradition and protecting the stable structures of life (Safety, Conformity and Tradition). The second dimension opposes the value, emphasizing accepting others as equals and caring for their welfare (Universalism and Benevolence), values accenting the desire to succeed and dominate others (Power and Achievement). Hedonism is associated with both Openness to change and Overcoming the "I". Our study presents the compared types of values preferred by hospice, missionary and sports volunteers.

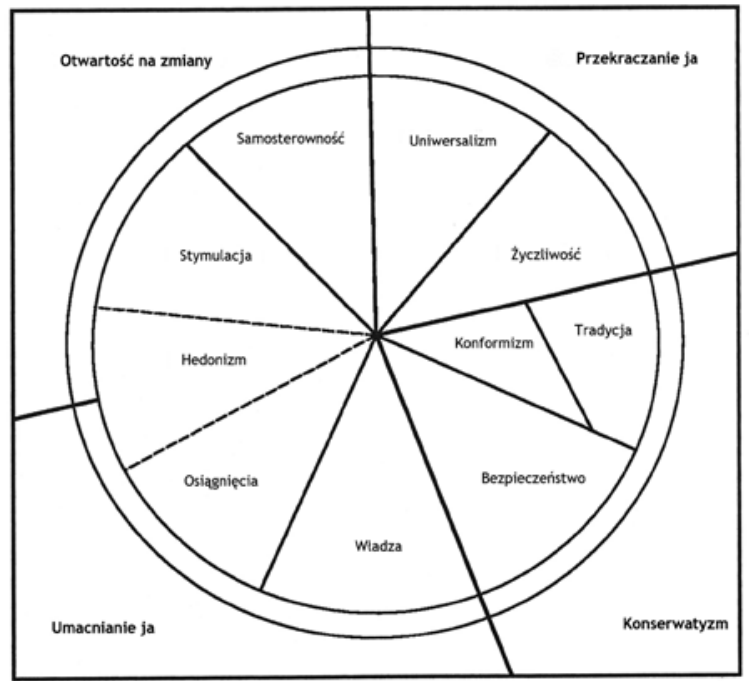

Figure 1. Theoretical model of the relationship between types of values (cf.: Schwartz, Huismans, 1995).

\section{The Problem and Hypotheses}

The object of this study is to analyze the motivation for service behavior among hospice, missionary and sports volunteers. Intergroup comparisons were made with regard to endo- and exocentric morals and the values system. The subject of verification were the following hypotheses: 
H1. Volunteers involved in hospice, missionary and sports volunteer work differ in endo- and exocentric motivation: a high level of exocentric motivation is expected in the hospice group and will be lowest in the sports group.

$\mathrm{H} 2$. The studied volunteer groups vary in the range of preferred values: in the group of hospice and mission volunteers, we expected a higher preference of values representing overcoming the "I" (universalism and benevolence) as compared to the sports group. In the group of sports volunteers, we expected a higher preference for values associated with strengthening the "I" that is, greater success, power and hedonism than in the hospice and missionary groups.

\section{The Subjects of the Study}

The study involved 173 people aged 16 to $77(\mathrm{M}=30.00, \mathrm{SD}=12.34)$, 111 women and $62 \mathrm{men}$. The hospice volunteer group included 59 people, the mission group included 63, and the sports group added up to 51. Most of the respondents completed secondary education (60.1\%) and higher education (32.9\%). $5.8 \%$ of these people completed only primary education, and $1.2 \%$ had only vocational education. The distribution in terms of the respondents' living areas was the following: the inhabitants of villages and small towns (up to 10,00o inhabitants) accounted for $15.6 \%$ of the respondents; residents of medium-sized cities (10,000-100,000 inhabitants) included $14.5 \%$, and the people living in large cities (over 100,000 inhabitants) added up to $69.9 \%$.

\section{Research Methodology}

The endo- and exocrentric morality questionnaire (KEEM). Developed by Karyłowski, Górska and Wasiak ${ }^{36}$, the KEEM is used to assess individual differences concerning relative endo- or exocentric motivation superiority in regulating pro-social behaviors. The method consists of seven short stories, each of which represents a person in a situation with a moral dilemma. Every story includes 24 arguments, 12 for providing assistance and 12 against helping. The set of arguments justifying granting assistance reflects the motivation, of which

${ }^{36}$ J. Karyłowski, Socjalizacyjne determinaty endo- egzocentryzmu moralnego, pp. 77-88; J. Karyłowski, O dwóch typach altruizmu. 
6 reflect exocentric motivation and 6 represent endocentric motivation. The set of arguments justifying the failure to provide assistance is a type of buffer. The purpose of the test is for the subject to decide whether she or he would provide help or not grant assistance to a person in need and the motives that drive them to do so. For this purpose, from a given list of 24 arguments, they select from 5 to 10 statements that best reflect their thoughts and feelings in a given situation.

Endo- and exocentrism is a bipolar variable. The numerical indicator of moral endo- or exocentrism is the proportion of the endo- and exocentric response calculated on the basis of their stance towards all of the stories. ${ }^{37}$ The method can be applied only when interviewing people who are known to be capable of disinterested work for the benefit of other people. ${ }^{38}$ Therefore, we can examine people currently involved in various forms of assistance activities (the external criterion) or in each case we must check their willingness to perform prosocial behavior by using another tool. The presented study fulfilled the external criterion for this, so there was no need to use additional tools to measure people's readiness for pro-social behavior.

The reliability of the KEEM test is $0.65(\mathrm{~N}=120)$. The rationale for the accuracy of the method is not very high but there is a significant correlation $(\mathrm{r}=0.37, \mathrm{~N}=53)$ with a focus on the "self" measured by the Self-Centeredness Associative Test. ${ }^{39}$

The Portrait Value Questionnaire (PVQ). The PVQ is a Polish translation of the English methods for analyzing the Schwartz value system. The method consists of 40 items, which are brief text descriptions (portraits) of various people. Each person is presented in terms of personal goals, aspirations and desires in reference to values. For example: "It is very important for him that his homeland is safe. He believes that his country must be protected against internal and external threats." A respondent uses each portrait to answer the question: "To what extent is this person similar to you?".

His or her response is expressed on a 6-point scale from 1 (very similar to me) to 6 (completely unlike me). The importance of the value is calculated using the arithmetic mean of all the statements it measured. Forty positions on the PQV

${ }^{37}$ Karyłowski calculated the measurement for exo- and endocentric morality using the numerical results.

38 J. Karyłowski, O dwóch typach altruizmu.

${ }^{39}$ Cf. J. Karyłowski, O dwóch typach altruizmu; T. Szustrowa, Zdolności do działania na rzecz celów pozaosobistych a niektóre właściwości rodzinnego treningu wychowawczego, „Zeszyty Naukowe Instytutu Psychologii UW” 1 (1972), pp. 12-41. 
create 10 scales (cf. Table 1 ). The number of entries in the scale is from 2 to 6 . Research carried out in many cultural circles confirmed its reliability, as well as the PVQ's converging and differential accuracy (Schwartz et al. 2001). Reliability was measured by the Cronbach $\alpha$-specific scales and amounted to: Conformity (o.63), Tradition (0.59), Kindness (o.68), Universalism (o.77), Self-directing (0.63), Stimulation (o.66), Hedonism (o.80), Success (o.73), Power (o.66) and Safety (o.66). The authors of the Polish translation of the methods are Zaleski and Żywiec. ${ }^{40}$

\section{Results}

The differences between hospice, mission and sports volunteers in the area of endo- and exocentric morality and values preference were determined by analyzing the ANOVA variants.

The ANOVA did not show statistically significant differences between hospice, mission and sports volunteers concerning endo- and exocentric motivation. All groups obtained results that were higher than 0.50 , showing higher exocentric motivation. All people tested, irrespective of the type of volunteer work they were involved in, are characterized by a stronger concentration on the external world and striving to respond to the needs of other people and the environment rather than the need to build a positive self-image. The highest average was obtained by hospice volunteers $(\mathrm{M}=0.63 ; \mathrm{SC}=0.17)$, and the lowest was for mission volunteers $(\mathrm{M}=0.57 ; \mathrm{SD}=0.15)$.

The comparison of volunteers in the area of preferred values showed seven types of values that are essential for differentiating the test group: tradition, hedonism, success, power, self-direction, stimulation and universalism (cf. Table 2). The values which most strongly diversify the studied group of volunteers are success and power. Both are most highly valued by sports volunteers, and are less important for hospice volunteers. Similarly, hedonism and stimulation are the most preferred values for sports volunteers, but are least valued by hospice volunteers. Tradition is the highest value for mission volunteers, next by the hospice and least of all by the sports volunteers. Universalism is a greater value for mission volunteers than for sports volunteers, and whilst mission volunteers are more self-directing than hospice volunteers.

${ }^{40}$ R. Żywiec, „System wartości a postawy wobec wybranych grup mniejszościowych u Polaków mieszkających w Polsce i za granicą”, (Unpublished MA Thesis, KUL, 2002). 
Table 2. A comparison of the values preferences among hospice, mission and sports volunteers. 41

\begin{tabular}{|c|c|c|c|c|c|c|c|c|c|c|c|}
\hline \multirow{2}{*}{ VALUES } & \multicolumn{2}{|c|}{ Hospice } & \multicolumn{2}{|c|}{ Mission } & \multicolumn{2}{|c|}{ Sports } & \multirow{2}{*}{$\mathrm{F}$} & \multirow{2}{*}{$p$} & \multicolumn{3}{|c|}{ Post hoc } \\
\hline & M & SD & M & SD & M & SD & & & $1: 2$ & $1: 3$ & $2: 3$ \\
\hline Conformism & 12.90 & 4.07 & 12.37 & 3.24 & 11.80 & 3.30 & 1.29 & - & - & - & - \\
\hline Tradition & 12.22 & 4.01 & 10.65 & 3.21 & 14.20 & 3.36 & 14.10 & 0.001 & 0.041 & 0.011 & 0.001 \\
\hline Kindness & 8.10 & 2.99 & 7.63 & 2.11 & 8.57 & 3.11 & 1.64 & - & - & - & - \\
\hline Universalism & 13.03 & 4.46 & 13.97 & 3.09 & 14.67 & 4.41 & 3.13 & 0.05 & - & - & 0.065 \\
\hline $\begin{array}{l}\text { Self- } \\
\text {-directing }\end{array}$ & 10.29 & 3.53 & 8.97 & 2.69 & 9.02 & 3.57 & 3.08 & 0.05 & 0.069 & - & - \\
\hline Stimulation & 10.10 & 3.52 & 7.76 & 3.46 & 7.63 & 3.24 & 9.60 & 0.001 & 0.001 & 0.001 & - \\
\hline Hedonism & 13.17 & 3.49 & 11.43 & 3.37 & 9.84 & 3.11 & 13.70 & 0.001 & 0.012 & 0.000 & 0.033 \\
\hline Success & 16.54 & 3.27 & 13.00 & 3.85 & 11.10 & 4.07 & 30.70 & 0.001 & 0.000 & 0.000 & 0.020 \\
\hline Power & 14.90 & 2.43 & 13.24 & 2.83 & 11.49 & 2.96 & 21.20 & 0.001 & 0.003 & 0.000 & 0.003 \\
\hline Safety & 16.17 & 4.74 & 16.33 & 4.17 & 15.69 & 4.59 & 0.31 & - & - & - & - \\
\hline
\end{tabular}

Table 3 presents the values preferred by the study group of volunteers, taking into account their importance and hierarchy. The configuration of the first four values among hospice and mission volunteers is identical. Another order of values appeared among sports volunteers. Here, only self-directing takes third place, which is analogous to the hospice and mission groups. The most important value for sports volunteers is stimulation, and the next most preferred value is kindness. These same 3 values, even though they be in a different order, were high on the hierarchy of values for hospice and mission volunteers. Hedonism was significantly different, and among the sports group it obtained a high fourth place on the hierarchy. In turn, the least preferred values worth pointing out are hedonism and success among the hospice volunteers. The hospice group placed hedonism as 7 th, while it had greater significance in the other groups. The mission volunteers placed hedonism as 5 th, and the sports

41 The higher the average, the lower the importance of the value. 
group in 4th place. In turn, success is less important for hospice volunteers than for the mission and sports groups.

Table 3. The configuration of values according to their importance on the hierarchy among hospice, mission and sports volunteers:

\begin{tabular}{|c|l|l|l|}
\hline No. & Hospice & Mission & Sports \\
\hline 1 & Kindness & Kindness & Stimulation \\
\hline 2 & Stimulation & Stimulation & Kindness \\
\hline 3 & Self-directing & Self-directing & Self-directing \\
\hline 4 & Tradition & Tradition & Hedonism \\
\hline 5 & Conformism & Hedonism & Success \\
\hline 6 & Universalism & Conformism & Power \\
\hline 7 & Hedonism & Universalism & Conformism \\
\hline 8 & Power & Success & Tradition \\
\hline 9 & Safety & Power & Universalism \\
\hline 10 & Success & Safety & Safety \\
\hline
\end{tabular}

To sum up, we can state that the hospice and mission volunteers possess a similar configuration of values, being motivated to get involved in activities for other people, while the sports volunteers show a different order of values.

\section{Discussion of the Results}

The presented research attempted to analyze the motivation among people involved in various forms of volunteer work. Two sources of motivation were studied: endo- and exocentric morality and the system of values among volunteers involved in hospice, mission and sports programs. The obtained results allowed us to conclude that the entire study group, independent of the type 
of volunteer work they are involved in, are characterized by exocentric motivation. The subjects' attention concentrated on the external world, meaning the needs and feelings of the person in need or their environment, and not on their "I". The catalyst triggering assistance behavior is thus external, and the undertaken activity is motivated by striving to produce the desired changes in another person's situation or environment. Even though inter-group differences are not statistically significant, the highest level of exocentric motivation was noted among hospice volunteers. We can therefore carefully note that these people are characterized by a somewhat higher awareness and concentration on the needs of other people than the remaining groups. The confrontation with helplessness accompanying a suffering person can also stimulate sensitivity to the needs and feelings of a person who is in need (cf. Karyłowski, 1982a, 1982b; Śliwak, 2001). The obtained results, however, do not confirm the first hypothesis that assumes the existence of inter-group differences in the area of endo- and exocentric motivation. The obtained results require further research based on bigger tests, while also taking into account volunteers involved in other forms of activities.

The comparison of the values preference among the hospice, mission and sports volunteer groups was done in two ways. First, we set the inter-group differences in the area of 10 types of values described by Schwartz. Next we undertook a categorization of the values and remarks based on the level of their importance on a hierarchy. A comparison of the hierarchy of values revealed great similarity among values preferred by the volunteers in the studied groups. We can even say that the 4 highest values (kindness, stimulation, self-directing and tradition) appeared in an identical configuration among hospice and mission volunteers. This is shown by the similarity of these groups in their values system. Two of the 10 values (kindness and stimulation) obtained a high position on the hierarchy of every one of the studied groups of volunteers and did not differentiate the subjects in their statistical significance. We can therefore conclude that both hospice, mission volunteers, and sports volunteers are interested in the good of other people, and possess a great need for affiliation and positive interaction with other people. According to Schwartz ${ }^{42}$, people who prefer kindness are characterized by readiness to help and forgive, loyalty, honesty, a friendly attitude, mature love and responsibility. Representatives of each type of volunteer work are open to what is new, value challenges and willingly undertake risks.

${ }^{42} \mathrm{~S}$. Schwartz, Universals in the content and structure of values, pp. 1-65. 
They are characterized by a high need for autonomy, independence and keeping control of the environment. ${ }^{43}$

Similarities in the values of the volunteer groups has a superficial appearance. The test results differ in the level of importance given to individual values. Statistically significant differences concern: tradition, universalism, hedonism, success, power, self-directing and stimulation. Sports volunteers more highly value success, power and hedonism in comparison to hospice and mission volunteers. On the other hand, hospice volunteers obtained the lowest score in comparison to the other two groups for the results of success, power and hedonism.

An overview of these values consists in the distinction made by Schwartz that exceeds the dimension called the "I". ${ }^{44}$ We can therefore conclude that the prosocial activity of sports volunteers fits into the context of realizing personal goals and achieving success. The high valuation of power indicates the high sensitivity of this group on the social hierarchy, the perception of social interaction in terms of subordination and domination and the desire to achieve a high social status. ${ }^{45}$ In addition, the significantly higher preference for hedonism when compared to the hospice and missionary groups may suggest that the pleasures of life and enjoying life, for sports volunteers, by meeting their own needs, are important predictors in the decision-making processes prior to the undertaken activity and involvement.

Therefore, as established in the second hypothesis, the aspect strengthening the "I" is an important correlate of this group engaged in prosocial activities. Conversely, this aspect is least present in the process of motivating hospice volunteers. They are relatively less focused on the search for pleasure and the opportunity to meet their own needs, less oriented towards achieving success and social prestige or gaining power. In addition, hospice volunteers, less than other groups, value stimulation and self-directing. The search for excitement, an exciting life, the ability to create and explore reality, independent thinking and deciding for themselves are not important actuators in the motivational processes. Given the fact that stimulation and self-directing behavior comprise the dimension of openness to change, as defined by Schwartz. It can be concluded that hospice volunteers prefer a conservative and predictable life structure. The

${ }^{43}$ Cf. S. Schwartz, Universals in the content and structure of values, pp. 1-65. Ibid?

${ }^{44}$ Cf. S. Schwartz, Are there universal aspects in the structure and contents of human values?, pp. 19-45.

${ }^{45} \mathrm{~S}$. Schwartz, Universals in the content and structure of values, pp. 1-65. 
study did not confirm the second hypothesis in assuming that hospice volunteers, similar to the mission volunteers, more highly hold values that make up the dimension of overcoming the "I" (universalism and benevolence).

The last value that significantly differentiates the three groups is tradition: missionary volunteers value it the most, and sports volunteers the least. High sensitivity to cultural diversity and respect for the history and tradition of mission countries seem to be elements facilitating the acceptance of social standards of other nations and growing up in a missionary environment in which they come to live and work. The group of missionary volunteers is characterized by both: the respect for tradition and the preference for universalism - the members of this group valued higher (especially when compared to the sports volunteers) such things as: understanding, respect, tolerance, protecting other's property and the widely understood well-being of the world and nature.

The presented research studies are not without limitations. It is a fact that volunteers representing a broad age range took part in them (from 16 to 77 years of age), and this might have an effect on the obtained results. Unfortunately, the number of participants was not high enough to be able to categorize the subjects based on their age and thus carry out an analysis according to different age groups. Due to the use of self-description techniques for measuring the variables characterizing the moral evaluation, the subjects' evaluation of the social approval of these variables was also pointed out.

\section{Bibliography}

Antos E., Kowalik K., Kopański Z., Postrzeganie hospicjum i opieki paliatywnej przez wolontariuszy, (palliative care by charity workers). „Journal of Public Health, Nursing and Medical Rescue" (2012) 2, pp. 48-51.

Baczko A., Ogrocka A., Wolontariat, filantropia i 1\%: Raport z badań 2007, Warszawa 2008, Stowarzyszenie Klon/Jawor.

Basińska A., Nowak M., Motywowanie wolontariuszy, http://www.staff.amu.edu. pl/ wolimp/Do\%20pobrania:/article/100/Basinska_Anita_Nowak_Marek-Motywowanie_wolontariuszy.pdf (25.03.2015).

Basińska A., Nowak M., Motywowanie i motywacja do pracy wolontariuszy, Poznań 2010, WOLIMP.

Brzozowski P., Uniwersalność struktury wartości. Koncepcja Shaloma H. Schwartza, „Roczniki Psychologiczne” 5 (2002), pp. 27-52.

Cendrowski Z., Wolontariusze, Warszawa 1998, Zarząd Główny Szkolnego Związku Sportowego. Agencja „Promo Lider”. 
Cieciuch J., Kształtowanie sie systemu wartości od dzieciństwa do wczesnej dorosłości, Stare Kościeliska 2013, Wydawnictwo Liberi Libri.

Kaminski T., Praca socjalna i charytatywna, Warszawa 2004, Wydawnictwo Uniwersytetu Kardynała Stefana Wyszynskiego.

Kamiński T., Wolontariat w placówkach pomocy instytucjonalnej, „Roczniki Naukowe Caritas" 5 (2001), pp. 99-109.

Karylowski J., Two types of altruistic behavior, in: Cooperation and helping behavior, J. Grzelak, V. J. Derlega (eds.), Academic Press, New York 1982.

Karyłowski J., Explaining altruistic behavior, „Polish Psychological Bulletin” 1 (1977) 8, pp. 27-34.

Karyłowski J., Koncentracja na sobie i zawartość „ja” idealnego, a bezinteresowne działania na rzecz innych ludzi, „Studia Psychologiczne” 1 (1977) 16, pp. 19-36.

Karyłowski J., O dwóch typach altruizmu: Badania nad endo-i egzocentrycznymi źródłami podejmowania bezinteresownych działań na rzecz innych ludzi, Wrocław 1982, Ossolineum.

Karyłowski J., Socjalizacyjne determinaty endo- egzocentryzmu moralnego, „Studia Psychologiczne" 2 (1982) 20, pp. 77-88.

Karyłowski J., Focus of attention and altruism: endocentric and exocentric sources of altruistic behavior, in: Development and Maintenance of Prosocial Behavior, E. Staub, D. Bar-Tal, J. Karylowski, J. Reykowski (eds.). International Perspectives on Positive Morality, Springer US, Boston, MA 1984.

Klimaszewska H., Wolontariat w służbie potrzebującym, in: Wolontariat $w$ służbie umierającemu, C. Opalach (ed.), Lubelskie Hospicjum dla Dzieci im. „Małego Księcia”, Lublin 2004.

Kochańska G., Regulatory theory of personality and the development of prosocial behaviors, in: Development and Maintenance of Prosocial Behavior, E. Staub, D. Bar-Tal, J. Karylowski, J. Reykowski (eds.). International Perspectives on Positive Morality, Springer US, Boston, MA 1984.

Kromolicka B., Wolontariusz w służbie człowiekowi umierającemu: Na przykładzie Szczecińskiego Hospicjum Domowego, Szczecin 2000, Pedagogium.

Ochman M., Jordan P., Jak pracować z wolontariuszami?, Warszawa 2000, Biuro Obsługi Ruchu Inicjatyw Społecznych BORIS.

Oliwa-Ciesielska M., Dobro jednostki versus dobro wspólne - paradoksy przeciwności, in: Wolontariat w obszarze humanistycznych wyzwań opiekuńczych, B. Kromolicka (ed.), Akapit, Toruń 2005.

Olubiński A., Humanistyczno-edukacyjne wartości wolontariatu w przygotowaniu do pracy socjalnej, in: Wolontariat w obszarze humanistycznych wyzwań opiekuńczych, B. Kromolicka (ed.), Akapit, Toruń 2005.

Pawłowski L., Lichodziejewska-Niemierko M., Wolontariat w opiece paliatywnej i hospicyjnej w Polsce-aspekty prawne, „Medycyna Paliatywna w Praktyce” 3 (2010) 4, pp. 125-132.

Pietrowski D., Wolontariat w Polsce - nowe spojrzenie na pracę społeczna, „Roczniki Naukowe Caritas" 5 (2001). 
Przewłocka J., Zaangażowanie społeczne Polaków w roku 2010: Wolontariat, filantropia, 1\%: raport z badań, Warszawa 2011, Stowarzyszenie Klon/Jawor.

Reykowski J., Motywacja, postawy prospołeczne a osobowość, Warszawa 1979, Państwowe Wydawnictwo Naukowe.

Rushton J., The altruistic personality, in: Altruism and helping behavior, J. Philippe Rushton, R. M. Sorrentino (eds.). Social, personality, and developmental perspectives, L. Erlbaum Associates, Hillsdale, NJ 1981.

Schwartz S., Universals in the content and structure of values, „Advances in experimental social psychology" (1992) 25, pp. 1-65.

Schwartz S., Are there universal aspects in the structure and contents of human values?"Journal of social issues" 4 (1994) 50, pp. 19-45.

Schwartz S., Rubel-Lifschitz T., Cross-national variation in the size of sex differences in values, „Journal of personality and social psychology" 1 (2009) 97, pp. 171-185.

Staub E., Positive social behavior and morality: Social and personal influences, New York 1978, Academic Press.

Szustrowa T., Zdolności do działania na rzecz celów pozaosobistych a niektóre właściwości rodzinnego treningu wychowawczego, „Zeszyty Naukowe Instytutu Psychologii UW" 1 (1972), pp. 12-41.

Śliwak J., Altruizm a preferencja wartosci. Badania empiryczne, „Roczniki Filozoficzne” 4 (1996), pp. 111-146.

Śliwak J., Altruizm endo-i egzocentryczny a poziom niepokoju, „Analecta Cracoviensia” (1996) 28, pp. 143-159.

Śliwak J., Osobowość altruistyczna: Osobowościowe korelaty altruizmu: psychologiczne badania empiryczne, Lublin 2001, Redakcja Wydawnictw Katolickiego Uniwersytetu Lubelskiego.

Śliwak J., Niepokój a poziom altruizmu, „Przegląd Psychologiczny: organ Polskiego Towarzystwa Psychologicznego" (2002).

Śliwak J., Zdunek M., Wolontariat - bezinteresowna działanie na rzecz potrzebującego, in: Psychospołeczne problemy zatrudnienia osób niepełnosprawnych, J. Śliwak (ed.), Norbertinum, Lublin 2007.

Walden-Gałuszko K. de, Opieka holistyczna, in: Podręcznik koordynatora wolontariatu hospicyjnego, P. Krakowiak, J. Binnebesel, K. de Walden-Gałuszko, A. Modlińska (eds.), „Via Medica”, Gdańsk 2008.

Witkowski L., Człowiek i profesjonalizm w pracy socjalnej (czyli jak bronić wolontariat przed woluntaryzmem - spojrzenie filozofa), in: Wolontariat w obszarze humanistycznych wyzwań opiekuńczych, B. Kromolicka (ed.), Akapit, Toruń 2005.

Żywiec, R., „System wartości a postawy wobec wybranych grup mniejszościowych u Polaków mieszkających w Polsce i za granicą", (Unpublished MA Thesis, KUL, 2002). 